\title{
ARTICLE
}

\section{The language of power: the politics of translation between English and Chinese in early colonial Hong Kong'}

\author{
Man Kong Wong \\ History Department, Hong Kong Baptist University, Hong Kong \\ Email: mkwong@hkbu.edu.hk
}

\begin{abstract}
Although Chinese was not an official language in early colonial Hong Kong, translation between English and Chinese played a crucial role in daily life and politics. The first part of this article discusses the making of some important translated terms for government units and departments as well as foreign consulates in Hong Kong. In doing so, it accounts for different approaches in translation and lexical innovation, and their historical significance behind the making of newly translated terms. The second part of this article investigates salient features of the translation experiment initiated by Governor John Pope Hennessy (1834-1891; term of office: 1877-1882). The experiment aimed at strengthening the political legitimacy and colonial governability in Hong Kong. In return, the social standing of Chinese community leaders was duly recognised through their association with translation projects between English and Chinese, and the presentation of translated messages at important occasions hosted by Government House.
\end{abstract}

Keywords: Translation or transliteration; lexical innovation; political role of translation

\section{Introduction}

The history of translation between English and Chinese in early colonial Hong Kong reveals some salient features of colonialism at work there. Since the Hong Kong government established English as the lingua franca in governance and the economy in a population where only a few knew it, translation as the bridge between two languages became a necessity. Moreover, the practice of translation in the history of early colonial Hong Kong offers a lens through which to understand features of the cultural interaction taking place between Britain and China in the nineteenth century. The choice of corresponding terms in these translated messages could carry new connotations that may have created impacts either intended or unintended upon their reception, making the political and cultural symbolism behind the practice of translation during Hong Kong's early years a topic

\footnotetext{
${ }^{1}$ A note about romanisation is necessary. Throughout the article, pinyin is adopted and appears before Chinese characters. But some examples are in Cantonese, and the digit that follows indicate the tone number. In order to differentiate between pinyin and Cantonese, the latter and its corresponding Chinese characters are underlined. As far as people's names are concerned, the respect of historicity is observed. If a certain Chinese name is transliterated in the historic text, its spelling is kept; for example, $\mathrm{Ng}$ Choy but not Wu Cai is used in this article.

(c) The Author(s), 2022. Published by Cambridge University Press on behalf of The Royal Asiatic Society. This is an Open Access article, distributed under the terms of the Creative Commons Attribution licence (https://creativecommons.org/licenses/by/4.0/), which permits unrestricted re-use, distribution, and reproduction in any medium, provided the original work is properly cited.
} 
of great significance. Take the story unfolding in a court scene that was recorded by William Tarrant (1820-1872), and retold by Ernest John Eitel (1838-1908): ${ }^{2}$

Magistrate: Collins-Collins, I say.

Collins: $\quad$ Your Honour!

Magistrate: Did not that witness say fan kwai in his evidence?

Collins: He did, your Honour!

Magistrate: Then take him out of the Court and give him three lashes!

(Lashes administered). And now, Interpreter, tell the witness that when he speaks of an English in this Court he must call him hung mo kwai.

The truth probably was that the witness said, after having given his evidence, "fan kwai" (fangui 翻歸; Cantonese: faan1 gwai1, i.e. "May I go home?"). The words fan kwai (fangui 番鬼; Cantonese: faan 1 gwai2, i.e. “foreign devil,") mean, when pronounced in a different tone, fan kwai, to go home.

The meanings of "going home" and "calling a Westerner a foreign devil" are clearly totally different. And so this story reveals a British magistrate's limit of patience in early colonial Hong Kong. What bothered him was not the word gui 鬼 (ghost) but fan 番 (foreign), which conveys a derogatory notion-barbarian. The opposite of "foreign" is "home". The irony was that the majority of the population in Hong Kong-the Chinese-did not speak or write English, which remained a totally foreign language to them. The same limitation was true as far as the majority of British were concerned, since they could not write and speak in Chinese, a "home" language for most of the population. The issue for the British was how to make the Chinese language, however "foreign", home (for example, forbidding the Chinese from using the phrase "foreign devil" in Chinese) or to make the Chinese accept the British people, the "foreign", home. In theory, there were no occasions when official translation was required since Chinese was not an official language. But in practice, translation had been a feature of people's daily life since the advent of British colonial rule in Hong Kong.

Studies on the history of translation in modern China-in particular, the pioneering works by James Hevia, Lydia Liu, Federico Masini, Michael Lackner, and others-have highlighted a number of salient features involved in the historical process of making modern Chinese lexicons. ${ }^{3}$ Hevia's perceptive study shows, for example, how translation could function as a weapon in Sino-British relations. ${ }^{4}$ In early colonial Hong Kong, a product of Sino-British relations, translating between English and Chinese became a device, if not a weapon, in local politics. Among other studies that discuss various aspects of the politics of translation in early colonial Hong Kong, Martha Cheung has argued how missionaries used translation to define and defend their own ideological concerns. Chan Man Sing has likewise discussed the qualities of some early translators' works, while Gillian Bickley has

\footnotetext{
${ }^{2}$ E. J. Eitel, 'Chinese Studies and Official Interpretation in the Colony of Hong Kong', China Review 6, 1 (July 1877), p. 5.

${ }^{3}$ James Hevia, English Lessons: The Pedagogy of Imperialism in Nineteenth-Century China (Durham and Hong Kong, 2003); Lydia Liu, Translingual Practice: Literature, National Culture, and Translated Modernity-China, 1900-1937 (Stanford, 1995); Federico Masini, The Formation of Modern Chinese Lexicon and its Evolution toward a National Language: The Period from 1840 to 1898 (Berkeley, 1993); Michael Lackner (ed.), New Terms for New Ideas: Western Knowledge and Lexical Change in Late Imperial China (Leiden, 2001); and Michael Lackner and Natascha Vittinghoff (eds.), Mapping Meanings: the Field of New Learning in Late Qing China (Leiden, 2004).

${ }^{4}$ Hevia, English Lessons, pp. 57-61.
} 
written about the activites of some early government translators. Wong Man Kong has examined the uses of sinological writings in nineteenth-century Hong Kong through the translation examples provided by James Legge (1815-1897) and Eitel in their involvement in missionary activities and colonial administration. ${ }^{5}$ But the question of the patterns and principles behind the practice of translation between English and Chinese against the changing historical contexts of Hong Kong is yet to be attempted. Accordingly, this article seeks to fill this gap. In what follows, it first compares and discusses a number of important translated terms. It then provides an account of the shortlived translation experiment initiated by Hong Kong's colonial authorities during John Pope Hennessy's governorship.

\title{
II. Setting the names correct through translations
}

\author{
If names be not correct, language is not in \\ accordance with the truth of things. \\ If language be not in accordance with the \\ truth of things, affairs cannot be carried on to success. ${ }^{6}$ \\ (James Legge's translation of Analects)
}

Confucius pinpoints the necessity of setting names correctly when managing public affairs and conducting businesses. In early colonial Hong Kong, it was imperative that conventionally accepted translated terms for certain official titles and government departments and units be established so that colonial rulers and their Chinese subjects alike could conduct their businesses in a language that would cause the least confusion. Uganda Kwan's study has illustrated the political implications behind the Chinese-translated title of the "Governor of Hong Kong", and how this translation commanded instant respect and contributed to the elevation of governors' political standing when interacting with top officials from the Qing court in the nineteenth century. ${ }^{7}$

We might assume that the same would be true when it came to other translations of official titles within the Hong Kong government. A casual reading of historical sources, however, highlights that some translated titles were convoluted and, on occasion, puzzling. Unsurprisingly, many factors account for the lexical innovations and variations

\footnotetext{
${ }^{5}$ Martha Cheung, 'Translation and Power: A Hong Kong Case Study', in Among the Best: Stephen C. Soong Chinese Translation Studies Awards 1994-2004, (ed.) Eva Hung, Vol. 2 (Hong Kong, 2005), pp. 82-100; Martha Cheung, 'Cong Zaoqi Xianggang de Fanyi Huadong (1842-1900) Kan Fanyi yu Quanki de quanxi 從早期香港的翻譯活動 1842-1900) 看 翻譯與權力的關係' [Translation and Power: The Protestant Missionary-Translators in Hong Kong (1842-1900)], in Fanyi di Lilun Jiangou yu Wenhua Toushi 翻譯的理論建構與文化透視 [Theoretical Construction of Translation from Cultural Perspectives], (ed.) Xie Tianzhen [謝天振] (Shanghai, 2000), pp. 292-309; Chan Man Sing 'The Translation of E. J. Eitel and Others: Translators in Hong Kong in the Nineteenth Century', and Gillian Bickley, 'The Student-Interpreters' Scheme and the Chinese Teacher's Allowance: Translator Education in Nineteenth Century Hong Kong', both in Translation in Hong Kong: Past, Present and Future, (ed.) Chan Sin Wai (Hong Kong, 2001), pp. 9-36; Wong Man Kong, 'The Uses of Sinology in the Nineteenth Century: Two Perspectives Revealed in the History of Hong Kong', in Colonial Hong Kong and Modern China: Interaction and Reintegration, (ed.) Lee Pui-tak (Hong Kong, 2005), pp. 135-154.

${ }^{6}$ The Chinese Classics: With a Translation, Critical and Exegetical Notes, Prolegomena, and Copious Indexes, reprint edition (Hong Kong, 1960), Vol. 1, pp. 263-264.

${ }^{7}$ Uganda Sze-pui Kwan 關詩珮, ‘Qinjin zhongguo? Qu zhongguo hua? Cong wan qing xianggang “zongdu” de fanyi dao jie zhímín 'teshou’ de shiyong’ 親近中國? 去中國化? 從晚清香港「總督」的翻譯到解殖民「特 首」的使用 [To Embrace Chinese? To De-Sinicize? The Translation of the Term 'Governor' in Late Qing Period and the Use of the Term 'Chief Executive' in Post-Colonial Hong Kong], 編譯論叢 Compilation and Translation Review 3, 2 (September 2010), pp. 1-31.
} 
that made translation possible in early colonial Hong Kong. These unfamiliar terms and their changes over time, therefore, offer a lens through which to explore how political, social, and cultural values were attached to the making of such translations.

The following section is divided chronologically to discuss the evolving practice of translation, drawing on some newly translated terms, some of which were rejected, while others were renovated and so became usable for a longer time. More specifically, it covers the 1860s, the 1870s, the 1890s, and the 1930s. Within each of these periods, I draw upon four different corpora of terms to show changes in translation regarding particular terms that were, in one way or another, commonly used as the standard in Hong Kong during their respective historical periods. These are found in The China Directory, ${ }^{8}$ The China Directory for 1874, ${ }^{9}$ John Chalmers' (1825-1899) An English and Cantonese Dictionary, ${ }^{10}$ and Dai Dongpei's (戴東培) Gangqiao xuzhi (《港僑須知》) [A Guidebook for Overseas Chinese in Hong Kong]. ${ }^{11}$ Published by China Mail, a leading English newspaper widely circulating in Hong Kong and China Coast, both 1861 and 1874 editions of China Directory were meant to facilitate direct communication and they included only conventionally accepted translations for government units and departments as well as companies. Accuracy seems to have been a key concern of the publisher in order to make the directory reliable and thus marketable. The same applied to A Guide for Overseas Chinese in Hong Kong. A word about the choice of John Chalmers' dictionary is necessary here. Chalmers was a serious translator who undertook due diligence in all his translation projects. ${ }^{12}$ In the preface to his An English and Cantonese Dictionary, he made it clear that "this dictionary was from the first intended for English people, rather than Chinese". ${ }^{13}$ Chalmers made reference to other similar dictionary projects. The two dictionaries by William Lobscheid (1822-1890) and Eitel, for example, were of a more substantial size. ${ }^{14}$ However, their length could have had an negative impact on their popularity. Chalmers' dictionary, at 296 pages in length, was more portable and thus became a more popular choice for contemporary users. His translated terms as well as those that he collected from his predecessors and contemporaries can be taken as a reliable representation of the period. Moreover, Chalmers paid attention to popular terms being used in Hong Kong to make it a suitable text for comparison in this study.

\section{I. The $1860 \mathrm{~s}$}

First, the Chinese-translated titles of government departments based upon Chinese equivalents in corresponding departments or units within the Qing court facilitated among the public some understanding of the duties and functions they performed, despite the fact that Hong Kong had a British colonial structure. But it should be noted that they did not carry the exact titles in their corresponding counterpart, illustrated by the following examples: Colonial Government (duxian yamen 督憲衙門), Magistracy (xunli ting 巡理 廳), and Gaol (jianfang 監房).

\footnotetext{
${ }^{8}$ The China Directory (Hong Kong, 1861).

${ }^{9}$ The China Directory for 1874 (Hong Kong, 1874).

${ }^{10}$ John Chalmers, An English and Cantonese Dictionary, revised edn (Hong Kong, 1893).

${ }^{11}$ Dai Dongpei, Gangqiao xuzhi (《港僑須知》) (A Guidebook for Overseas Chinese in Hong Kong) (Hong Kong, 1933).

${ }^{12}$ For a discussion of the quality of Chalmers' translation of Daodejing, see Wong Man Kong, 'Nineteenth Century Missionary-Scholars at Work: A Critical Review of English Translations of Daodejing by John Chalmers and James Legge', Monumenta Serica 63 (2015), pp. 124-149.

${ }^{13}$ Chalmers, An English and Cantonese Dictionary, p. vii.

${ }^{14}$ William Lobscheid, English and Chinese Dictionary: With the Punti and Mandarin Pronunciation (Hong Kong, 18661868) [2,013 pp.], and Ernest John Eitel, A Chinese Dictionary in the Cantonese Dialect (Hong Kong, 1877) [1,018 pp.].
} 
Some Chinese translated terms were straightforward, showing the functional nature of the positions concerned, with examples including Registrar General (huamin zhengwusi 華 民政務司), Surveyor General (liangdi guan 量地官), Harbour Master (chuantou guan 船頭 官), Police and Lighting rates (shou chaiyi jiedeng xiangfang 收差役街燈餉房), and Post Office (Shuxinguan 書信館).

However, other Chinese translated terms were the result of processes of lexical innovation achieved through a combination of the transliteration of names of office bearers and their offices. In doing so, the literary focus of the translated terms was not the functional nature of the departments. Take the following examples (the underlined part of the term shows the place where Cantonese transliteration is adopted): Colonial Secretary (William Thomas Mercer, Masha xiezilou [Cantonese: maa1 saa1] 孖沙寫字樓), Treasury (Frederick H. A. Forth, Ke xiezilou [Cantonese: fo1] 科寫字樓), Auditor General (W. H. Rennie, Lianyi xiezilou [Cantonese: lin4 ji3] 連意寫字樓), U.S. Consulate (James Keenan, Qinan huaqi lingshiguan [Cantonese: kei4 naan4] 其難花旗領事館), U.S. naval depot (William Speiden Jr., Shibeidun [Cantonese: si6 pai3 deon6] 士俾頓), and H.M. Naval Department (William M. Richards, Liechashi shuishi chuanliaoju [Cantonese: lit6 caa4 si6] 列查士水師船料局). The personnel involved were meant to carry a heavier weight than that of the functional office. In other words, the public, and ordinary Chinese in particular, were encouraged to recognise the persons involved more than the functional nature attached to the position. But changes in office bearers made it necessary to adopt a new translation for the same office. Naturally, such changes caused confusion and these terms were later rejected in the 1870s.

of many such transliterated terms, there was an interesting case that shows a combination of Chinese literary sense and transliteration, namely the translation of the Supreme Court-“Dage 大葛”. The Cantonese pronunciation of the second character “Ge 葛 (Cantonese: got3)" resembles the English pronunciation of "court". The first character "Da 大” (great) carried the connotation of being important and superior. The practice of using " $D a$ " was seen in other translated terms for institutions commanding a higher order of prestige. For example, Police was translated "Daguan 大館”; church or chapel was translated as “Libaitang 禮拜堂”; while St John's Cathedral was “Dalibaitang 大禮拜 堂”. Another interesting feature is that a number of different Chinese words were used to refer to different units and departments, namely yamen 衙門, si 司, guan 官, xiezilou 寫字樓, fang 房, and guan 館. The former three were of a more official nature, signifying a superior notion, while the latter three were somewhat unassuming. Confusingly, such differences did not necessarily reflect the hierachical rank of the officials concerned within the colonial administration.

of all the translated terms during the 1860s, one interesting case illustrates the reversed order of authority within the colonial context, but it concerns not the British but the Spanish. This was the translated term for the Spanish Consulate in Hong Kong, which was translated as “Lusong lingshiguan 呂宋領事官”. Here the colony Lusong 呂宋 (Luzon) became the representation of its sovereign state-Spain. Interestingly, throughout the nineteenth century, Lusong had become a standardised translation for Spain in Hong Kong. ${ }^{15}$ Indeed, it was more than a nineteenth-century Hong Kong translation since the term had a deeper root in the Chinese language. Lusong had first appeared in Chinese texts during the Song Dynasty. Then during the Ming Dynasty, Dongxi yangkao 東西洋 考 (Studies in Eastern and Western Oceans), written by Zhang Xie 張毃 (1574-1640), mentioned the early conquest of Lusong by Portugal. Yet, he did not mention the subsequent domination by the Spaniards. Zhang's text became the source for the Qing court to imagine the situation in Luzon. In Huangqing jigongtu 皇清職貢圖 (The Portraits of

\footnotetext{
${ }^{15}$ In the two English-Chinese texts produced in 1874 and 1891, Spain was translated as Lusong “呂宋”.
} 


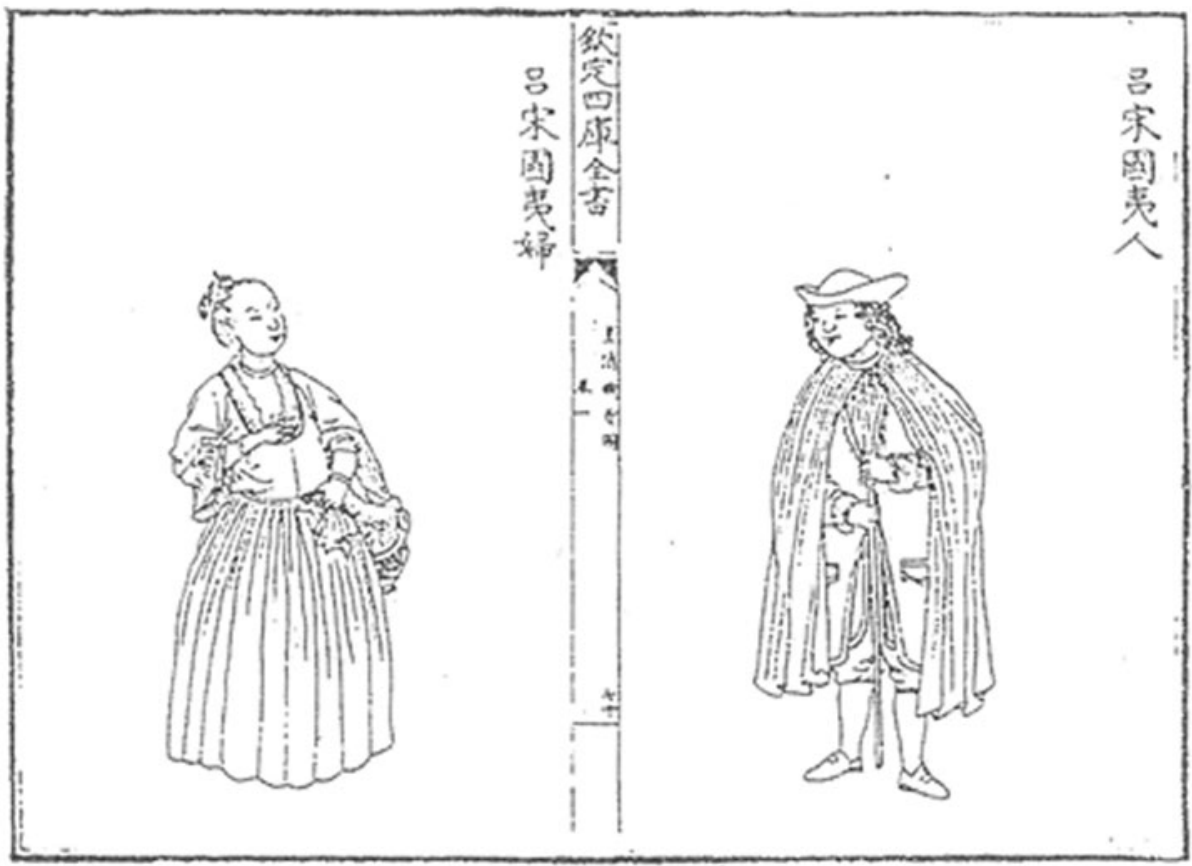

Figure I. The Spaniards were called the "Barbarians from Luzon" in Huangqing Jigongtu (I76I, p. 70). Source: Collected in Ji Yun (comp.), Qinding Si ku quan shu (Beijing, 1803).

Periodical Offering during Qing Dynasty) of 1761, collected in the Qinding Siku quanshuco 欽定 四庫全書 (The Imperial Edition of the Complete Library of the Four Treasuries), the Spaniards in Luzon were depicted as “barbarians from Luzon” (Lusongguo yiren 呂宋國夷人), as shown in Figure 1.

In other words, the Chinese term Lusong (Luzon) had become an umbrella term covered the people who inhabited Luzon, indigenous tribes and the Spaniards alike, and covered its sovereign state within the Spanish colonial structure. It remains unknown why the Spanish did not oppose such usage by the Chinese. And once it had become a conventionally accepted term among the Chinese, it did not seem to invoke much sensitivity when used as a standard translated term in colonial Hong Kong although it upset the hierarchical order of sovereign-colonial relationship. Meanwhile, there was no single example in which 'Hong Kong' was used to represent 'Britain'.

\subsection{The $1870 \mathrm{~s}$}

By the 1870s, some earlier translated terms had become standardised. These included the Chinese translation for Registrar-General, Surveyor-General, Police, Post Office, Gaol, and Magistracy. Yet, there was variation in the translation of official titles. These included Colonial Government (duxian shu 總憲署, previously duxian yamen 督憲衙門), Harbour Master (chuanzheng ting 船政廳, previously chuantou guan 船頭官), and Supreme Court (niexian yamen 臬憲衙門, previously Dage 大葛). Among these three titles, the new Chinese translation of the Supreme Court corresponded to a similar unit under the Qing court. In effect, transliteration was given up in the practice of translation. Similarly, the practice of transliterating the names of office bearers, such as Colonial 
Secretary (zongdu yamen 總督衙門), Treasury (kuwu si 庫務司), U.S. Consulate (da huaqi lingshiguan 大花旗領事館), and H.M. Naval Department (shuishi tidu 水師提督), was now dropped,

However, it would be wrong to assume the use of transliteration in translation had come to a complete end. In cases where the Chinese equivalent could not be found within the Qing court, transliteration remained in use. Hence, “官 (guan)” and “署 (shu)” were adopted to create new translated terms. It was indeed a combined mode. While there was no Chinese match for "engineer" at that time, the terms "royal engineers" and “Royal Engineer Department” were transliterated into “yinjianniye guan 烟賤尼也官 (Cantonese: jin1 zin6 nei4 jaa5)” and “Yinjianniye shu 烟賤尼也署(Cantonese: jin1 zin6 nei4 jaa5)" respectively. It is interesting to note that the above terms involved the use of a derogatory word-jian 賤 (despicable/immoral/cruel/low-price). For understandable reasons, the word jian is avoided in Chinese titles or names. There are other choices that capture the tonic note of that part of the English word in the Chinese transliterated terms. The reason why it was first coined as such is not known. Neither is it possible to identify who initially devised the word. What we can be certain of, however, is that the term was soon replaced.

Finally, the 1870s saw the creation of terms for existing or new government councils and departments. Such examples included Executive Council (yizheng zongju 議政總局), Legislative Council (dingli zongju 定例總局), Central School (da shuyuan 大書院), Fire Brigade (xianggang jiuhuo renyuan 香港救火人員), Marriage Registration Office (hunyin shiwusi 婚姻事務司), Lock Hospital (xiyingpan yisheng guan 西營盤醫生館), Vice Admiralty Court (ancha si 按察司), and Royal Artillery (paobing fang 炮兵房). These newly translated terms were intended to elucidate the functions of concerned units. The Chinese translation for Vice-Admiralty Court as Anchasi 按察司, for instance, was an adoption from a senior Chinese official whose duty was to take charge of legal jurisdiction, namely the Superintendent of Judicature. ${ }^{16}$ As happened in the 1860s, terms in the 1870 s consisted of a number of different Chinese words to carry the official titles, namely " ju 局”, “si 司”, “renyuan 人員”, “fang 房”, and “guan 館”. Consequently, we may safely argue that the order of hierarchy, vertical and horizon, as conveyed in Chinese terms was not developed through any attempt to establish any structure among translated terms.

Finally, the Chinese translation of names for foreign nations for their respective consulates in Hong Kong, Macao, and Canton was not always the same. Of the ten consulates cited in the China Directory for 1874, three are the same or nearly the same in both Hong Kong and Macao, and two are the same in Hong Kong and Canton: the former include Austria-Hungary (Yadieliya 雅爹厘啞), Belgium (Da beizhian guo 大卑之暗國; Beizhian 卑 之暗-Macao), and Italy (Da yidali guo 大意打厘國; yidali 意打德 Macao), while the latter comprised France (Da faguo 大法國) and Sweden and Norway (Shiweidun ji Naweiguo 士威 頓及那威國). The one term that was nearly the same in all three places was Spain ( $D a$ lusong guo 大呂宋國 Hong Kong and Canton; Lusong guo 呂宋國-Macao). But there were also cases of difference. Imperial Germany, for one, was translated differently- $D a$ rierman guo 大日耳曼國 in Hong Kong, Boluosi guo 波羅斯國 in Macao, and Da de guo 大德國 in Canton. Similarly the United States was Da huaqi guo 大花旗國 in Hong Kong, and $\mathrm{Da}$ mei guo 大美國 in Canton. Some literati with a transnational outlook in nineteenth-century China had already written about other parts of the world. Xu Jiyu 徐繼檑 (1795-1873), for example, compiled the Yinghuan Zhilue 瀛環志略 (Short Records of the World) in 1848 and revised it in $1866 .{ }^{17}$ The translated terms for these nations had already appeared in Xu's book, namely Austria-Hungary (Aodiliya 奧地利亞),

\footnotetext{
${ }^{16}$ E. J. Eitel, 'Chinese Official Ranks', China Review 3, 6 (1875), p. 379.

${ }^{17}$ Fred W. Drake, China Charts the World: Hsu Chi-yu and His Geography of 1848 (Cambridge, 1975).
} 
Belgium (Bilishi 比利時), Italy (Yidali lieguo 意大里列國), France (Folangxi 佛郎西), Sweden (Ruiguo 瑞國), Spain (Xibanya 西班牙), Imperial Germany (Rierman lieguo 日耳曼列國), and the United States (Milijian 米利堅). These variations suggest that Hong Kong did not necessarily copy from nearby places where people spoke a similar dialect, nor did those others follow Hong Kong. Furthermore, the prevailing translation in books by official literati in South China, despite geographical proximity and political authority over cultural arenas, did not necessarily find their way into the practice of translation between English and Chinese in Hong Kong.

\subsection{Comparing the 1890s and the 1930s}

After nearly half a century of colonial rule from the 1890s to 1930s, the practice of translating official titles and terms had accumulated enough breadth and depth to pave the way for standardisation, such as Colonial Secretary (Fuzheng si 輔政司), Treasury (Kuwu si 庫務司), and Registrar General ${ }^{18}$ (Huamin zhengwu si 華民政務司). In a similar fashion, some terms were slightly modified, such as Executive Council (from Yizheng zongju 議政總局 to Yizheng ju 議政局), Legislative Council (from Dingli zongju 定例總局 to Dingli ju 定例局), and Harbour Master (from Chuanzheng ting 船政廳 to Chuanzheng ju 船政局). Yet, it would be wrong to assume that all translated terms required no revision, and we can see these changes in the following cases: Colonial Governor (from Zongxian 總憲 to Zongdu 總督), ${ }^{19}$ Supreme Court (from Nie shu 臬署 to Gaodeng shenpan ting 高等審判廳), Magistracy (from Xunli fu 巡理府 to Caipan sishu 裁判司署), Gaol and Prison $^{20}$ (from Jian fang 監房 to Jian yu 監獄), Surveyor-General (from Liangdi guan 量 地官 to Celiang si 測量司), Police (from Xunbu ting 巡捕廳 to Jing shu 警署), Post Office (from Shuxin guan 書信館 to Youzheng ju 郵政局), Fire Brigade (from Xianggang huojiu renyuan 香港救火人員 to Miehuo zongju 滅火總局), and Royal Engineers (from Da ji 大 計 to Gongcheng shi 工程師). These changes were in parallel with language modifications after the fall of Qing dynasty, which itself created a new order of meaning in Chinese terms for offices and titles. ${ }^{21}$ The question of how language changes in China influenced the creation and usage of similar terms in Hong Kong, and vice versa, is as yet to be researched.

\section{The translation experiment (I879-I882)}

In February 1974, the Official Languages Ordinance was passed, after which the Chinese language began to be given the same level of recognition as the English language in Hong Kong. Consequently, the Hong Kong government conducted its businesses both in English and Chinese. Not surprisingly, the Hong Kong government spent resources on translation. In other words, it was not legally necessary to conduct government administration in the Chinese language before 1974. This might lead us to assume that there was no attempt on the part of the government to introduce any translation project prior to this date. But this presumption would mean overlooking the translation experiment

\footnotetext{
${ }^{18}$ The Registrar General was renamed Secretary for Chinese Affairs in 1912.

${ }^{19}$ Uganda Kwan points out that Governor of Hong Kong had been translated as Zongdu 總督 since the very early colonial period. She does not clearly specify the exact date when such a translation became standardised, though. See Kwan, 'Qīnjìn zhōngguó? Qù zhōngguó huà?'. Her findings do not rule out the possibility that there were variations in the usage of Chinese translated terms for the Governor.

${ }^{20}$ In 1920, Goal was renamed Prison.

${ }^{21}$ John de Francis (1911-2009) was the authority in charge of modern Chinese language after 1911. Of his numerous publications, two are of particular relevance here, namely Nationalism and Language Reform in China (New Jersey, 1950), and The Chinese Language: fact and fantasy (Honolulu, 1984).
} 
carried out between 1879 and 1882. This experiment was initiated by the then Hong Kong Governor John Pope Hennessy, carried out by Eitel, and ended when Hennessy left the colony. The following section discusses the salient features of official translation under this experiment.

A few words about the background are first necessary, however. From the outset, missionaries were pioneering agents in the practice of translation in Hong Kong. The religious call was their reason to become missionaries; becoming translators was probably a result of their scholarly disposition. In nineteenth-century Hong Kong, key missionarytranslators included Charles Gutzlaff (1803-1851), Lobscheid, Legge, Chalmers, and Eitel. Thanks to their knowledge of the Chinese language and Chinese culture, they became de facto advisers who assisted the British colonial government in its interactions with the local Chinese community. ${ }^{22}$

of these missionaries, Eitel played a key role in the translation experiment under Hennessy. Prior to this, he was invited by the previous Governor Arthur Edward Kennedy (1809-1883; term of office 1872-1877) to chair the Schoolbook Committee, which aimed at preparing "a set of three graduated readers after the pattern of the Irish National Schoolbook Society's publication”. This marked the beginning of Eitel's approximately 20 years of involvement in educational affairs in Hong Kong. The committee's purpose was to help "conciliate objections" to the grant-in-aid scheme introduced in 1873, which was opposed by the Catholic Church in Hong Kong. ${ }^{23}$ The main issue was the lack of proper Chinese textbooks for schools that received government grants. The use of Confucian or any other Chinese texts was deemed to be the government's deliberate promotion of 'heathen' education. Such criticism was a result of the Catholic Church's intention to fight for more autonomy in the design of the curriculum in their aided schools. As a missionary and sinologist, Eitel had the knowledge and sensitivity regarding both religious issues and the quality of Chinese texts for educational purposes. When it came to these two objectives, he was expected to strike the right balance. Afterwards, he became a member of the Board of Examiners that was to "encourage and direct the study of the Chinese language on the part of Government officers", and later he was appointed the Superintendent of Chinese Studies, a position created to justify his position within the Hong Kong government. ${ }^{24}$ Under Hennessy, as the Governor's Chinese Secretary and the Inspector of schools, Eitel was responsible for translating official reports and papers into Chinese.

Hennessy was the key person driving the translation experiment. Historians Lowe and McLaughlin have described him as "an Irish, Catholic, reform-minded, 'pro-native' Governor". ${ }^{25}$ Subsequent to Hong Kong, he became Governor of Mauritius, where his motto was "Mauritius for the Mauritians". ${ }^{26}$ Hence, during his time in Hong Kong, he was keen to improve the overall policies towards the local Chinese population, ${ }^{27}$ which for him meant improving communication between them and the government. Eitel was

\footnotetext{
${ }^{22}$ Wong, 'The Use of Sinology'.

${ }^{23}$ E. J. Eitel, Europe in China: The History of Hong Kong from the Beginning to the Year of 1882 (London, 1895), p. 511.

${ }^{24}$ Ibid., p. 481.

${ }^{25}$ Kate Lowe and Eugene McLaughlin, 'Sir John Pope Hennessy and the "Native Race Craze": Colonial Government in Hong Kong, 1877-1882', The Journal of Imperial and Commonwealth History 20, 2 (May 1992), p. 224.

${ }^{26}$ For a fascinating discussion on Hennessy's legacy in Mauritius, see Kenneth Ballhatchet, 'The Structure of British Official Attitudes: Colonial Mauritius, 1883-1968', The Historical Journal 38, 4 (1995), pp. 989-991.

${ }^{27}$ For a discussion on Hennessy's Chinese policies in Hong Kong, see She Yao Ting, 'The Chinese Policies of John Pope Hennessy in Hong Kong' (unpublished MPhil thesis, The Chinese University of Hong Kong, 1988); Jeanette Bresnihan, 'The governorship of Sir John Pope Hennessy, 1877-82: Reform and Foreign Policy' (unpublished MPhil thesis, The University of Hong Kong, 1990); and Poon Shuk Wah, 'Five Years of 'Mischievous Activity’: A Study of Governor Hennessy’s Policies towards the Chinese in Hong Kong, 1877-1882' (unpublished
} 
thus a key go-between. A certain number of government notices, tenders, bills, ordinances, and other documents were translated and published in The Hong Kong Government Gazette between 1879 and 1882. Besides the annual Administrative Reports published by the Hong Kong government, it was only the education report that was translated and published in both languages. As Inspector of Schools, Eitel was responsible for educational matters and writing the annual report was one of his official duties. For obvious reasons, he had to produce a Chinese translation of his education reports. After Hennessy left Hong Kong, the provision of a Chinese translation alongside the English report in gazettes and administrative reports ended. While Eitel remained in the same position until his retirement in 1897, the fact that he did not provide any Chinese translations of his education reports after Hennessy's departure suggests that the Governor played a more decisive role than Eitel in this translation experiment. But these translated texts provide us with an interesting lens through which to access how the practice of translation was conducted. The ways in which English was translated into Chinese revealed the political and social circumstances under which the colonial authority and prestige was maintained.

\section{I. The precedence of the English language over the Chinese}

From 1879 to 1882, The Hong Kong Government Gazette repeated the same notification at the start of each year, highlighting that the English version took precedence if there was ever a discrepancy in meaning between the original and its Chinese translation. The notification read as follows: "Translation into Chinese, for the information of the Chinese portion of the Community, of some of the Government Notifications are inserted herein, but it is to be understood that in case of variance in the sense of the English and Chinese versions, the sense of English text must be considered as correct." ${ }^{28}$ Clearly, the English language enjoyed precedence over Chinese in the practice of translation: in other words, English was the only official language in Hong Kong.

\subsection{Unfaithful translation? Expanding the contents for targeted audiences}

Of all the items published in The Hong Kong Government Gazette, notices from magistrates are of particular interest for historians because they provide substance for further reflection on facets of Hong Kong society, ranging from issues about law and order to the nature of colonial rule. ${ }^{29}$ In the first few issues of the Gazette, the Chinese translations were of newly added contents to that which appeared in the English ones. Not only did the Chinese versions (see examples provided in Tables 1 and 2) contain more information about offenders and, information that the English versions did not cover, they also served the function of colonial governability, warning the Chinese to stay vigilant and not to commit any similar crimes, while using such standard Chinese idioms as yijing xiaoyou 以儆效尤 and yizhao jiongjie 以昭炣戒.

But such practices did not last long. In subsequent reports, the translation was carried out in closer accordance with the English version. What needs to be pointed out is that the English original contained more details than the earlier pieces, though the message of admonishment was dropped in the Chinese translation. Table 3 provides another example.

MPhil thesis, Hong Kong Baptist University, 1995). These theses do not discuss the practice of translation under his term of governorship, however.

${ }^{28}$ The first notification of this kind appeared in the Government Gazette that was published on 3 January 1879.

${ }^{29}$ For an interesting discussion of how a magistrate conducted his duties in office, see Gillian Bickley (ed.), A Magistrate's Court in Nineteenth Century Hong Kong: Court in Time (Hong Kong, 2009). 
Table I: Retailing prepared opium without a licence ${ }^{30}$

\begin{tabular}{|c|c|}
\hline The original & $\begin{array}{l}\text { Fined } \$ 60 \text { or two months' imprisonment, and the prepared opium } \\
\text { found to go to the Opium Farmer, together with a moiety of the penalty } \\
\text { if paid. }\end{array}$ \\
\hline $\begin{array}{l}\text { The Chinese translation } \\
\text { (punctuation added) }\end{array}$ & $\begin{array}{l}\text { 高泰者, 南海人也。為於九月十九日在港之匯源里, 私者洋煙被 } \\
\text { 巡差見之控之於官。本月十四日, 票傳到審官斷其有違例禁, } \\
\text { 判罰銀六十員, 不完罰疑[款]監禁兩個月抵消, 所煮之煙盡行 } \\
\text { 充公。以儆效尤。 }\end{array}$ \\
\hline $\begin{array}{l}\text { The English translation of the } \\
\text { Chinese translation }\end{array}$ & $\begin{array}{l}\text { Gao Tai was a native of Nanhai. He was caught selling prepared opium } \\
\text { without license on } 19 \text { September in Hui Yuan Lane. On } 14^{\text {th }} \text { of this } \\
\text { month, he was called to the court and the magistrate ruled that Gao } \\
\text { breached the law and had to be fined } \$ 60 \text {. The fine was collected in } \\
\text { lieu of two months' imprisonment. The prepared opium was to be } \\
\text { confiscated. It was to deter people from committing a similar crime. }\end{array}$ \\
\hline
\end{tabular}

Table 2: Embezzlement by a servant of $\$ 25$ of the monies of his master ${ }^{31}$

\begin{tabular}{|c|c|}
\hline The original & $\begin{array}{l}\text { Sentenced to four months' imprisonment, the last fourteen days to be in } \\
\text { solitary confinement, the rest with hard labour. }\end{array}$ \\
\hline $\begin{array}{l}\text { The Chinese translation } \\
\text { (punctuation added) }\end{array}$ & $\begin{array}{l}\text { 海豐李亞長, 行年三十四, 役司管店。為於本月十四日, 伊之東主 } \\
\text { 交二十五元銀紙一張, 囑往找換, 詎李長膽敢携銀前往賭館, 盡 } \\
\text { 行輸了。為東主知覺, 呼差拿獲, 送案究治, 官斷監禁苦工四個 } \\
\text { 月, 監期將滿前十四日, 困於黑牢, 以昭畑戒。 }\end{array}$ \\
\hline $\begin{array}{l}\text { The English translation of } \\
\text { Chinese translation }\end{array}$ & $\begin{array}{l}\text { A native of Haifeng, } \mathrm{Li} \text { Yachang was } 34 \text { of age and he worked as a } \\
\text { shopkeeper. On } 14^{\text {th }} \text { of this month, his employer asked him to } \\
\text { exchange a } \$ 25 \text { banknote with the loose change. But he bet and lost } \\
\text { the money at a gambling house. The employer reported the police, and } \\
\text { the magistrate sentenced him to four months' imprisonment with hard } \\
\text { labour, the last fourteen days in solitary confinement. It was to deter } \\
\text { people from committing a similar crime. }\end{array}$ \\
\hline
\end{tabular}

Table 3: A case of Larceny ${ }^{32}$

\begin{tabular}{ll}
\hline The original & $\begin{array}{l}\text { Lok A-pui, a hawker, was sentenced on the 26th January to three months' } \\
\text { imprisonment with hard labour, for stealing some articles of clothing and } \\
\text { a brass smoking pipe, the property of Chu Tai-gan, in the Un U brothel, at } \\
\text { Square Street. }\end{array}$ \\
\hline $\begin{array}{c}\text { The Chinese translation } \\
\text { (punctuation added) }\end{array}$ & $\begin{array}{c}\text { 駱培小販也, 於英正月廿六日, 因在四方街煥意娼院, 竊去妓婦朱 } \\
\text { 帶銀衣服數件, 並水烟袋一枝, 被拘到案斷作苦工三個月。 }\end{array}$ \\
\hline
\end{tabular}

In the practice of translation, one of the ground rules is to translate according to the prevailing literary standards of the receiving end. The use of certain popular cultural images would be a customary practice. For example, the term "god of fire (Zhurong 祝融)" was used in the Chinese translation of a government notification concerning the setting

\footnotetext{
30 'Summary of cases deserving notice decided at the magistracy, during the week ending $9^{\text {th }}$ January 1879', The Hong Kong Government Gazette (15 January 1879), p. 19.

31 Ibid.

32 'Summary of cases deserving notice decided at the magistracy, from $17^{\text {th }}$ January to $31^{\text {st }}$ January 1879 , both days inclusive', The Hong Kong Government Gazette (5 February 1879), p. 45.
} 
off of crackers during Chinese New Year. The original stated: "His Excellency the Governor desires the Chinese public to take special precautions on this occasion, as the unusual dryness of weather increases the danger of a conflagration arising in case of careless handling of Crackers." The danger of a conflagration was translated as chunu Zhurong 觸怒祝融 (angering Zhurong). ${ }^{33}$ It was probably a result of the recognition of the Chinese taboo against saying disastrous or unfortunate things at the auspicious time of celebrating Chinese New Year. Under a different circumstance-the death of Empress Dowager Cian (慈安太后 18371881)-the Hong Kong government expressed condolence in both languages. In the Chinese translation, Eitel translated the English word “death" as sheng xia 升遐 (ascendancy to heaven/immortality), Chinese terminology used specifically to refer to the passing of a ruler. ${ }^{34}$ In other words, he avoided using the taboo word of si 死 (death) in the Chinese translation. Again, it was a polite act of conveying a sense of profound respect for the Qing court.

\subsection{The politics of translating the Governor's speeches}

Students of Hong Kong history would not fail to recognise the function of The Hong Kong Government Gazette for the dissemination of general information, such as the appointment of senior officials, bills and ordinances, legal tenders, and major case reports from courts and magistrates. Seldom were Governors' speeches published in the Gazette. Rather, they were reported in local English newspapers. ${ }^{35}$ Among the materials published in the Gazette during these four years, there were two sets of Governors' speeches that were delivered in the presence of leading members of the local Chinese community at Government House. These occasions marked an unprecedented degree of recognition of Chinese leaders whose words were accurately conveyed through translation and published both in English and Chinese on the pages of the Gazette.

The first occasion was the visit of Ulysses S. Grant (1822-1885: President of the United States 1869-1877) to Hong Kong. On 3 May 1879, Hennessy welcomed him with a banquet at Government House, the same place where he subsequently arranged a meeting with the local deputation from the Chinese community. ${ }^{36}$ Since Hong Kong had become a British colony, there had been occasional visits by British royal family members and top Chinese officials. Yet, the diplomatic and political significance of the visit of a recent American president was unmatched. Diplomatic protocol was to be observed. The Governor attached great significance of Grant's contribution: Hennessy quoted the incumbent Prime Minister Lord Beaconsfield (Benjamin Disraeli 1804-1881; two terms of office as Prime Minister, 1868 and 1874-1880) as follows: "the future of civilisation is indissolubly bound up in the future of the United States-those other achievements, accompanied by the toleration, resolute strength, and love of justice of the statesman, when the sword of the soldier was laid aside". Its Chinese translation reads “Jianglai wanguo jiaohui zhishi 將 來萬國教化之事, duanlai Meiguo zhixingshuai 端賴美國之興衰, ji wushi shiqi bingwei 即 武士釋其兵威, wenchen cunqi yadu er zhuanxin zhizhi suo chengjiu zhe 文臣存其雅度而專 心致至所成就者”. What Hennessy was referring to here was the Civil War in the United States which he sought to reference without raising any embarrassment over the political clashes between different sectors in American society, the North and the South. Rather, as he put it in a roundabout fashion, Grant had been fighting for the true notion of

\footnotetext{
${ }^{33}$ The Hong Kong Government Gazette (15 January 1879), p. 19.

${ }^{34}$ The Hong Kong Government Gazette (23 April 1881), p. 273 (see Figure 2 in the Appendix).

${ }^{35}$ For example, Governor Hennessy delivered a speech at the Central School on 30 January 1880, which was first reported in full in the Hong Kong Daily Press and then subsequently reprinted in the gazette. See 'Address of His Excellency the Governor at the Central School', The Hong Kong Government Gazette (4 February 1880), pp. 95-98.

${ }^{36}$ The Hong Kong Government Gazette (14 May 1879), pp. 245-248.
} 
"Freedom", a noble cause that Hennessy himself endorsed as well as being something that upright British politicians embraced. While writing and translating such a subtle message, Hennessy could not afford to ignore Grant's fight for freedom as the cornerstone for the future of human civilisation. In this way, British superiority was reinforced through Hennessy's claim that both shared the same sense of noble duty in defending freedom and a similar concern over the future of human civilisation.

The keyword here was 'freedom' and how to translate it represented an important question in the context of colonial Hong Kong. Obviously, the translation was never meant to facilitate any philosophical discussion over the notion of freedom. It is, therefore, not necessary to engage in discussion here on how Chinese literati understood political philosophies concerning liberty, freedom, and other related issues in the nineteenth century. ${ }^{37}$ Rather the political connotations of this translated term within the colonial context of Hong Kong will be discussed.

In his speech, the Chinese translation for "freedom" was craftily rendered as "Zili zhidao 自理之道”, conveying the meaning of a way of self-management. The political intention behind this new coinage becomes clear when we compare it to how Lobscheid had translated it in his dictionary in Hong Kong in the mid-1860s. Lobscheid's dictionary remained the most comprehensive one available at that time. Lobscheid translated "freedom" as “Zizhuzhe自主者” (a free/independent individual), “Zhiji zhiquan 治己之權” (the rights to self-govern), and "Renyixing zhi quan 任意行之權” (the right to do whatsoever one desires). ${ }^{38}$ But it seems that Lobscheid's translation was not adopted as the colonial authorities did not want to encourage the Chinese in Hong Kong to believe that they were entitled to self-government or had the right to do whatsoever they desired as free and independent individuals. For example, the colonial government had imposed a curfew on the Chinese in Hong Kong since the 1840s. ${ }^{39}$ The new coinage, thus, avoided the question of "rights", which was done with mild political implications. In these circumstances, the use of "selfmanagement" reinforced the roles that Chinese social leaders played in charitable institutions such as the District Watchmen Committee, the Tung Wah Hospital, and the Po Leung Kuk. In so doing, it confirmed the way that the British governed Hong Kong society by extending recognition to these kinds of Chinese social leaders.

Furthermore, Hennessy's interpretation of Grant's contribution during the American Civil War-fighting for people's freedom-appealed to the leading Chinese merchants in Hong Kong. At the time of Grant's visit, there was growing anti-Chinese sentiment not only in California but in the United States more widely. ${ }^{40}$ Hong Kong was the most important port in South China through which most outgoing Chinese migrant workers left for the United States. Thus, the connection between Hong Kong and Overseas Chinese communities in the United States was more than simple fraternity in terms of coming from the same or nearby villages and counties but also contained huge commercial implications for the entire business of migrant workers. ${ }^{41}$ Before Grant's departure

\footnotetext{
${ }^{37}$ For the most recent discussion on the historical processes behind the making of Chinese terminology and ideology of freedom, see Max Huang, The Meaning of Freedom: Yan Fu and the Origins of Chinese Liberalism (Hong Kong, 2008).

${ }^{38}$ Lobscheid, English and Chinese Dictionary, p. 870.

${ }^{39}$ For a discussion of the position of Chinese people in Hong Kong, see Christopher Munn, Anglo- China: Chinese People and British Rule in Hong Kong, 1841-1880 (Richmond, 2001).

${ }^{40}$ Shih-shan Henry Tsai, China and the Overseas Chinese in the United States, 1868-1911 (Fayetteville, 1983), pp. 43-59.

${ }^{41}$ Within the 15 years from 1860 to $1874,112,362$ Chinese migrant workers left for the United States from the port of Hong Kong. The commercial opportunities involved were enormous. See Madeline Y. Hsu, Dreaming of Gold, Dreaming of Home: Transnationalism and Migration between the United States and South China, 1882-1943 (Stanford, 2000), pp. 31-32.
} 
from Hong Kong, Hennessy arranged for a local deputation of seven Chinese social leaders to meet the ex-President at Government House. This move was of particular political significance in terms of Hennessy winning support from the local Chinese community. The deputation was led by Ng Choy 伍才(alias Ng Ting-fang 伍廷芳, 1842-1922, Chinese barrister at the Supreme Court of Hong Kong and subsequently the first Chinese legislator, whose term of office was 1880-1882). Again, the address was written in Chinese and translated into English so that Grant could understand its contents. Ng was instrumental in connecting the Governor with the leading Chinese community leaders. Hennessy's pro-Chinese attitude was attributed to Ng's influence. ${ }^{42}$

Against the background of the Exclusion Act in the United States that was then in the making, Ng Choy and other Chinese social leaders adopted a politically subtle approach when they submitted a petition to Grant asking for "a spirit of impartiality and fairness, treating Americans and Foreigners alike". Its core message emphasised extending the good and just policies to cover the Chinese in the United States as well-"Benefit to Chinese People [in the United States]” huiji huamin 惠及華民. The gift presented to Grant -a silk scroll of skilled embroidery on which the four Chinese words huiji huamin were sewn-conveyed the beauty of Chinese art and cultural esteem alongside the aforementioned political request to look after Overseas Chinese in the United States. ${ }^{43}$ In return, Grant stated that he was keenly aware of the good qualities of the Chinese people whom he had encountered during his tour of British colonies. His speech endowed status on the leaders of Hong Kong Chinese community, and the translation of the speech helped deliver this message. On the other hand, the encounter did not mean that Grant would necessarily help to obliterate or lessen prevailing anti-Chinese feelings in his home country.

One more observation deserves attention. In comparing the two versions, there was one slight variation. In his compliments to the Chinese people, Grant referred to their "good qualities of frugality, industry, and enterprise". In the Chinese version, it reads “jiwei pushi qinjian, yongyu weishan 極為樸實勤儉, 勇於為善 (very frugal and industrious, strongly committed to the charitable cause)". Since the translation was carried out by Eitel, the latter part was an addition that did not appear in Grant's original speech. Certainly, leading members of the Chinese community in Hong Kong, whose charitable deeds the British authorities wished to encourage, were heartened to read this new addition: hence, it served a useful purpose for colonial governance in Hong Kong.

The second occasion on which the Governor took advantage of translation was the presentation in 1881 of a "congratulatory address by the Chinese people, gentry and merchants of the whole colony". ${ }^{44}$ This address was co-signed by 57 leading members of the Hong Kong Chinese community who, in it, showed their appreciation for what they viewed as the good policies carried out by Hennessy over the previous four years. The authority of a Governor was usually regarded as intrinsic, and so, ironically, such a strong endorsement begged the question-was he not the most fitting Governor for Hong Kong? One possible explanation was that Hennessy wanted to show the Colonial Office back in London that he was a popular official whose rule in Hong Kong was effective. If this is true, then this translation presents a message with a much wider historical interest because Chinese community leaders had been negotiating a proper representation under colonial rule for years: ${ }^{45}$ "All we hope for is that His Excellency will, for a long time, continue to govern our people", read the English translation.

\footnotetext{
${ }^{42}$ Linda Pomerantz-Zhang, Wu Tingfang (1842-1922): Reform and Modernization in Modern Chinese History (Hong Kong, 1992), pp. 48-51.

${ }^{43}$ The Hong Kong Government Gazette (14 May 1879), p. 248.

${ }^{44}$ The Hong Kong Government Gazette (23 April 1881), pp. 274-278 (see Figure 2 in the Appendix).

${ }^{45}$ For a general background, see Chan Wai Kwan, The Making of Hong Kong Society: Three Studies of Class Formation in Early Hong Kong. (Oxford, 1991), pp. 122-131. It should be noted that, however, Chan failed to note this strong delegation of Chinese community leaders in the presentation of this message at the Government House.
} 
Hennessy eventually ended his term of office and left Hong Kong in March 1882. Hence, the timing of the address points to it having been a calculated move to strengthen Hennessy's case for extending his governorship. On the other hand, perhaps this move was merely calculated by the local Chinese community. The reality, however, was that the Colonial Office did not act according to the latter's wishes. Either way, it did not prove harmful to Hennessy, since the address and its English translation could serve as strong proof that he was not deserving of the British mercantile community's complaints to London. ${ }^{46}$

While the congratulatory address was jointly signed by over 50 leading Chinese, it did not indicate how many joined the deputation which delivered it to Government House on 22 April 1881. But regardless of the actual number, it was a powerful delegation of members of significant charitable and social organisations, such as the Tung Wah Hospital 東華醫 院, Po Leung Kuk 保良局, and Man Mo Temple 文武廟. ${ }^{47}$ Received as guests of honour, the group's leader, Fung Ming-shan 馮明珊 (d. 1898), a highly competent bilingual and a compradore of the Chartered Mercantile Bank in Hong Kong, ${ }^{48}$ read the address in Chinese, which was then translated into English by Eitel, ${ }^{49}$ though interestingly Fung could have translated the message himself. Translation remained in the hands of those who were in power. In this sense, translation had a clear political role to play in local politics.

At the beginning of his address, Fung honoured the Hong Kong Governor as if he were a member of Qing officialdom. Hennessy's qualities were highly praised, yet placed in abstract paternalistic terms, with governance and policies likened to familial care. According to Eitel's translation, local Chinese "look[ed] up to him as one of the bright spirits. . love [d] him as one loves one's parents". In the latter part of the address, Hennessy was described as a "merciful prince". No doubt, the address followed established Chinese lines. Hence, it would be wrong to read the English translation literally. Rather, it needs to be read culturally and socially. The address, in its translated form, appeared exotic, if not exaggerated, by the prevailing standards of the English language. However, as indicated earlier, if it had a political function to perform, Eitel made his translation mean what was intended, culturally and politically, in the original Chinese language.

Exotic as it may have appeared to English readers, the language used by Eitel adhered closely to the original text, conveying the style and favour of Fung's language as much as he could. But there are places where Eitel's translation may not have been the best possible choice. For example, he translated “Kuobei zaidao 口碑載道 zhonghui yici 眾喙一詞” as “[ $\mathrm{t}]$ he tablet of His Excellency's fame is exhibited in the streets, and multitudes proclaim it with one voice", and “wo huamin zhi heershide zhe 我華民之飲和而食德者 moshou caicheng yu wangwei 默受裁成於周外, yindao biyin yu wuqiong 隱叨庇蔭於無窮” as “[o]ur Chinese people, who have been drinking in his gentleness and feeding on his goodness, have silently experienced his educating influence beyond measure and tranquility enjoyed the shadow of his protection above all limit". The two Chinese idioms-kuobei zaidao 口碑 載道 and yinhe shide 飲和德—were excessively interpreted in Eitel's English translation. With respect to the former, it really does not have to put up a "tablet", as its translation reads, while its accurate meaning would be word of mouth which is the same praise. As to

\footnotetext{
${ }^{46}$ The British merchants in Hong Kong were so completely at odds with the Governor that they had written to the Colonial Secretary in London on several occasions to complain about Hennessy's pro-Chinese policies. See John Carroll, A Concise History of Hong Kong (Hong Kong, 2007), pp. 52-53.

${ }^{47}$ Concerning the social and political functions of Tung Wah Hospital, Po Leung Kuk, and Man Mo Temple Committee, see Kwan, The Making of Hong Kong Society.

${ }^{48}$ For a brief account of Fung, see May Holdsworth and Christopher Munn (eds.), Dictionary of Hong Kong Biography (Hong Kong, 2012), s.v. "Fung Ming-shan".

${ }^{49}$ It was recorded that Eitel was the translator of the address. See The Hong Kong Government Gazette (23 April 1881), p. 274 (see Figure 2 in the Appendix).
} 
the latter, it means to drink and eat well, and its extended meaning is to live well, which does not imply drinking and eating under Hennessy's gentleness and goodness.

In response to the goodwill and sincerity extended by the Chinese community, Hennessy made his own speech, which formed part of this same political act. He was interacting directly with Hong Kong Chinese leaders; indirectly, and probably more importantly, his aim was to make a strong impression on the Colonial Office in London. Politically, his speech sought to cultivate a good relationship with the local Chinese. He assured his Chinese audience that their contribution to making Hong Kong prosperous was duly recognised. Indeed, he attributed the success that he had had while Governor to "the industry of the people" and their "loyal and orderly disposition" (baixing zhi qinlao 百姓之勤勞 zhongjin liangshan 忠盡良善)—and the assistance that he received from competent Chinese leaders (huo anlian zhiren, suishi xiangli bentang, yi shanzhi huamin zhi langfa 獲諳練之人，隨時襄理本堂，以善治華民之良法). He acknowledged their contribution in fighting the crime of kidnapping, in founding an association (commonly known as the Po Leung Kuk), and in funding and managing the smallpox hospital.

On another level, Hennessy honoured the prestige of the British Empire by regularly referring to the Colonial Secretary whose 'wise' decision had helped to make a better Hong Kong. His speech even included a statement from the Colonial Secretary himself, which amounted to about one-third of the entire report. Hennessy also underlined that like himself, the Governor before him had been willing to receive views and opinions from the Chinese community. As he pointed out, the fight against kidnapping had been agreed and carried out by his predecessor: "in passing his Ordinance No. 2 of $1875,{ }^{50}$ Governor Arthur Kennedy had mentioned that he had introduced it at the solicitation of the leading members of the Chinese community". The Chinese translation read as follows: “chang yanming tiju gai zeli naiyin huaming shenshang kenbing suozhi 嘗言明提舉該則 例乃因華民紳商懇禀所致”. As Hennessy stated, “in everything relating to the well-being of the Colony, he was glad, at all times, to receive their counsel and co-operation": the Chinese translation reads: “fan she bengang gumin leye zhishi 凡涉本港居民樂業之事, ben butang chengyuan suishi wenqi suoyan 本部堂誠願隨時聞其所言, er leyu bitongxieli banli yan 而樂與彼同心協力辦理焉”. Again, Hennessy was making it evident to the Colonial Office why he was popular among the Hong Kong Chinese. In particular, he signalled that his open style of governance was conducive to the well-being of the colony. On the other hand, the Chinese version, accurately translated, helped to reinforce their cooperative and good deeds, while calling for more collaboration from the Chinese community.

\subsection{To translate or not to translate}

There is another important aspect of the language of power-to translate and not to translate. Of the many ordinances and their draft bills published in The Hong Kong Government Gazette, only a small number were translated. The same was true with government proclamations. The government did not feel it necessary to explain why some were translated and others were not. In theory, all ordinances and proclamations applied to everyone in Hong Kong: they had a similar degree of relevance to all communities. Some possible patterns behind what was translated can be identified, however. First and foremost, it served to enable the Chinese to understand new ordinances that had a direct impact on people's livelihoods and the maintenance of law and order. One obvious

\footnotetext{
${ }^{50}$ Ordinance No. 2 of 1875 reads: "For the better protection of Chinese Women and Female Children, and for the repression of certain abuses in relation to Chinese Emigration". See Hong Kong Blue Book for the Year of 1875, p. 44.
} 
example of this was the establishment of a monopoly of wine retailing-Spirit Farm-to control the sale of spirituous and fermented liquors. ${ }^{51}$ The Macao Extradition Ordinance provides another example: while the first and second readings of the draft bill were not translated, at its third reading the definitive version was duly published in both English and Chinese. ${ }^{52}$ As far as revenue collection was concerned, we see a similar pattern at work. The revision of the Excise Ordinance (Opium) and Rating Ordinance was first published in English and then, when it was passed, in both languages. Moreover, the government translated bills and ordinances that recognised the acquisition of British nationality through naturalisation. Cases of naturalisation were announced in both English and Chinese. The first batch of six cases-Fung Ming Shan, Wong She-tai 黃社 帶, Shi Shang-kai 施笙階, P'ang Im 彭炎, Ip Him-Kwong 葉謙光, and Un Man-Tsoi 袁 敏-were gazetted twice, as draft bill and passed ordinance, and both were in two languages. ${ }^{53}$ Subsequently, cases of naturalisation were gazetted only once. In 1882, for instance, two batches of cases were gazetted. The first group consisted of Lau Shun Ting 劉順廷, Chan Teng Cho 陳廷初, Ng Li Hing 吳利興, Yau Chong Peng 邱莊炳, and Chan Mun Wing 陳滿榮, ${ }^{54}$ while the second comprised Hu Wa 許華 and Ho Shun 何 順. ${ }^{55}$ Besides the legal requirement to gazette bills and ordinances, naturalisation represented an act of status-giving that affirmed the emergence of particular Chinese leaders in the community. Ironically, it was counterproductive to mix uptheir names, which happened to $\mathrm{Hu}$ and $\mathrm{Ho}$ as their English and Chinese names were wrongly matched.

However, not all ordinances that were translated concerned law and order, such as those concerning the control of Chinese passengers in the port of Hong Kong, ${ }^{56}$ penalty, ${ }^{57}$ flogging, ${ }^{58}$ prison regulations, ${ }^{59}$ as well as banishment and conditional pardons. ${ }^{60}$ The same was true of ordinances that directly related to the governance of economic activities, such as the construction of the tramway, ${ }^{61}$ the management of shipping, ${ }^{62}$ as well as market and business-related issues. ${ }^{63}$ This move contradicted Hennessy's original intention that such matters had to be translated for the Chinese population's general information, and instead points to the fact that the court was still not equally accessible for non-English speakers. We may well conclude that the British hold over legal matters

\footnotetext{
51 'To establish a Spirit Farm in the Colony and to consolidate and amend the Ordinances relating to Distilleries and to the Sale of Spirituous and Fermented Liquors', The Hong Kong Government Gazette (11 June 1879), pp. 305-330.

${ }^{52}$ The first draft was published on 5 March 1881, the second on 19 March 1881, and the third on 30 July 1881.

53 The first reading of the bill was recorded in The Hong Kong Government Gazette (18 June 1881), pp. 469-470. The ordinance was passed and published in The Hong Kong Government Gazette (25 June 1881), pp. 498-499.

${ }^{54}$ The Hong Kong Government Gazette (11 February 1882), pp. 122-123.

55 The Hong Kong Government Gazette (22 April 1882), p. 425.

${ }^{56}$ For example, 'An Act for the Regulation of Chinese Passenger Ships', The Hong Kong Government Gazette (11 February 1882), pp. 83-106.

${ }^{57}$ For example, 'The Penal Ordinances Amendment Ordinance, 1881', The Hong Kong Government Gazette (11 June 1881), p. 459.

${ }^{58}$ For example, 'To amend and repeal certain Ordinances relating to Branding and to the punishment of Flogging', The Hong Kong Government Gazette (19 November 1881), pp. 1006-1007.

${ }^{59}$ For example, 'The Prisons Regulations Amendment Ordinance, 1880', The Hong Kong Government Gazette (14 August 1880), pp. 608-609.

${ }^{60}$ For example, 'The Banishment and Conditional Pardons Ordinance, 1882', The Hong Kong Government Gazette (4 March 1882), pp. 225-226.

${ }^{61}$ For example, 'For authorizing the construction of certain Tramways within the Colony of Hong Kong', The Hong Kong Government Gazette (18 February 1882), pp. 141-173.

${ }^{62}$ For example, 'The Merchant Shipping Consolidation Ordinance Amendment Ordinance', The Hong Kong Government Gazette (14 August 1880), p. 609.

${ }^{63}$ For example, 'An Ordinance to make temporary provision for securing the status of French Mail Steamers within the Ports of the Colony of Hong Kong', The Hong Kong Government Gazette (14 August 1880), p. 609.
} 
remained absolute and unchallengeable: "The language of the law is English. The District and Supreme Courts function only in English, as does the Lands Tribunal", remarked eminent legal historian Peter Wesley-Smith in 1987, more than a century after Governor Hennessy's translation experiment. ${ }^{64}$

\section{Conclusion}

Translation was a major device in the exercise of the language of power during early colonial Hong Kong. The practice of translation, however, changed over time according to circumstantial factors linked to the political and socio-cultural context. The first part of this article, therefore, discussed key translated terms and their possible sources of inspiration. Some pointed to processes of cultural interaction taking place that involved selective borrowing from the prevailing terminology in nearby regions as well as adoption from standard Chinese. Equally important, there were also examples of lexical innovation that involved partial or full application of Cantonese transliteration in the making of new translations.

In the second part, the article then discussed how the colonial context made an impact on processes of English-Chinese translation, which allows light to be shed on salient features of colonialism in Hong Kong. Under the translation experiment, explored here, the patron-client relationship was clear in that all translated materials were used to promote the cause of colonial Governability. This government-sponsored initiative defended and consolidated the political legitimacy of colonial rule in Hong Kong in general, and the honour of the then Governor Hennessy in particular. Chinese social leaders also had a role to play in the politics of English-Chinese translation, which recognised and reinforced their high standing. By acknowledging their status, their social and political influence in Hong Kong was assured, whether through their subtle association with the process of English-Chinese translation or in their presentation of translated messages on important occasions at Government House.

${ }^{64}$ An Introduction to the Hong Kong Legal System (Hong Kong, 1987), p. 101.

Cite this article: Wong MK (2023). The language of power: the politics of translation between English and Chinese in early colonial Hong Kong. Journal of the Royal Asiatic Society 33, 155-177. https://doi.org/10.1017/ S1356186321000900 


\section{Appendix}

274 THE HONGKONG GOVERNMENT GAZETTE, 23RD APRIL, 1881.

\section{ADDRESS TO HIS EXCELLENCY THE GOVERNOR.}

On Friday, the 22nd instant, a deputation of the Chinese inhabitants of Hongkong called at Government House, and presented a congratalatory address to His Excellency Sir JoHs POPE Hexsrsssy. The deputation was introduced by Mr. Fuse Mrsc-shás, Chairman of the Society for the Protoction of Women and Children, who stated that the Directors of the Tung-wá Hospital, the Committee of the Man-mo Temple and the Provisional Committee of the Society for the Pro. tection of Women and Children, who formed this deputation, came on this day, the fourth anniversary of His Excellency the Governor's arrival in this Colony, to congratulate him on behalf of the whole Chinese community on the marked success, visible in the increased prosperity of the Colony, which bad attended his administration of the Government during the last four years.

Mr. Fuso Mrso-sHis then read, in Chinese, the subjoined address, which was forthwith translated into English by Dr. Eitre, who was present as Interpreter.

\section{(Translation.)}

\section{Cosoratulatóny Adpress by tie Chingse Prople, Gentry and Merchasts or the whols CoLosy.}

From of old, the essential element of good government consists in securing the affections of the people whilst maintaining dignity.

Since the arrival of our-Governor, Sir Jour Popz Hennessy, in this Colony, it is now, if we reckon it up one by one, exactly four years on this day. Going back in thought over the past, we feel a strong desire to speak out and give vent to the feelings which all along inspired us with confidence and hope. Tracing back to its fountain-head the constituent principle of Sir Jours Pops Hennessy's government, we find strict justice and clear impartiality, felicitous benevo. lence and tenacious earnestness. Those influences penetrated down to the humblest classes who settled here, whilst that humane kindness watched over all the people. His multifarious labours in removing oppression and fostering loyalty, and all the other measures of his effective government, are too numerous to count up. There is none among us Chinese who does not reverently look up to him as one of the bright spirits; there is none who does not love him as one loves one's parents. The last four years have passed as if they had been but a day.

Now venturing to advert briefly to a few of his measures, there is the grant of a public place for the interment of deserted human remains, and the donation be made, from his private purse, of over one thousand one hundred dollars, in per-

害督碩敬商綿民華

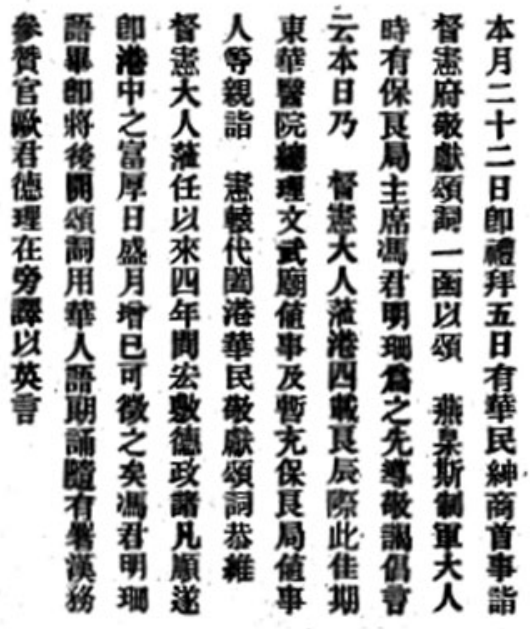

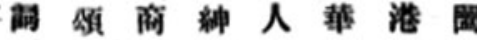

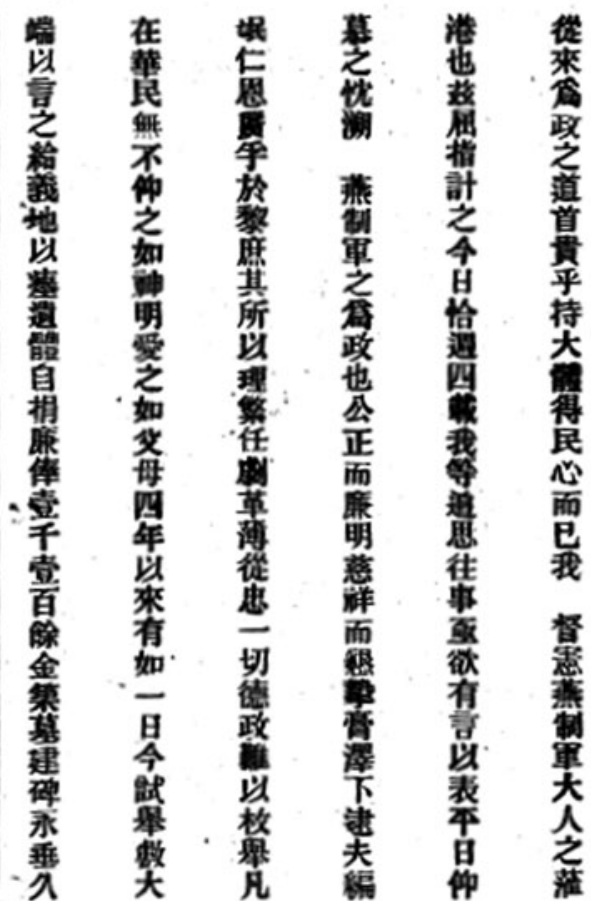

Figure 2. The Hong Kong Government Gazette (23 April I88I), pp. 274-278. 
manent commemoration whereof a tablet has been placed by us in the mausoleum built by him. Thus goodness experienced by the living, has extended its idfluence also to the bones of the dead. All that live and breathe join in one voice in expressing their obligations for this act.

The Tung-wá Hospital had an office for vaccination, but patients stricken with small-pox and seeking to be cured had no secluded ward to be received in;" wherefore he expressly granted a piece of ground for this special purpose, which was an act of merciful consideration for infants and highly meritorious protection of youthful lives.

His Excellency is designated by us as the merciful prince, and lauded by all far and near as such.

The practice of kidnapping was extremely extensive, and victims once fallen into the trap were engulfed in an.ocean of misery. But our Governor, prompted by sympathy and commiseration for those victims, established the Society for the Protection of Women and Children, to extend to them a saving hand, and thus his kindness is exhibited to the destitute and forlorn and his favour is shown to the women and children.

The tablet of His Excellency's fame is exhibited in the streets, and multitudes proclaim it with one voice.

The Chinese inhabitants of Hongkong who reside here, trusting to the protection of his government, number not far below two hundred thousand, and yet they have no meeting hall to promote the extension of their commence, but His Excellency expressly moved Her Majesty's Government to give them a piece of ground and a grant for the purpose of the proposed building, which act of protection and pacification is a matter of justice, prompted by a desire to tranquillize the people, to include all in one view of humane kindness, and to allow no distinctions of race or nationality.

The foregoing statement, explicit as it is, falls yet short of recounting one thousandth part of His Excellency the Governor's deep humanity and powerful liberality: Moreover, in these four years, whatever there was of advantage was sure to be promoted by him to its minute detail. Our Chinese people, who have been drinking. in his gentleness and feeding on his goodness, have silently experienced his educating influence beyond measure, and tranquilly enjoyed the shadow of his protection above all limit.

Having now, on this day, respectfully reached the fourth anniversary of His Excellency the Governor's arrival in Hongkong, all the Chinese inhabitants of the Colony, without exception, rejoice and exult in demonstrative pleasure, all looking upon the fact of our having this worthy Governor for the pastor of our people as the great happiness of our nation.

All we hope for is that His Excellency will, for a long time, continue to govern our people,

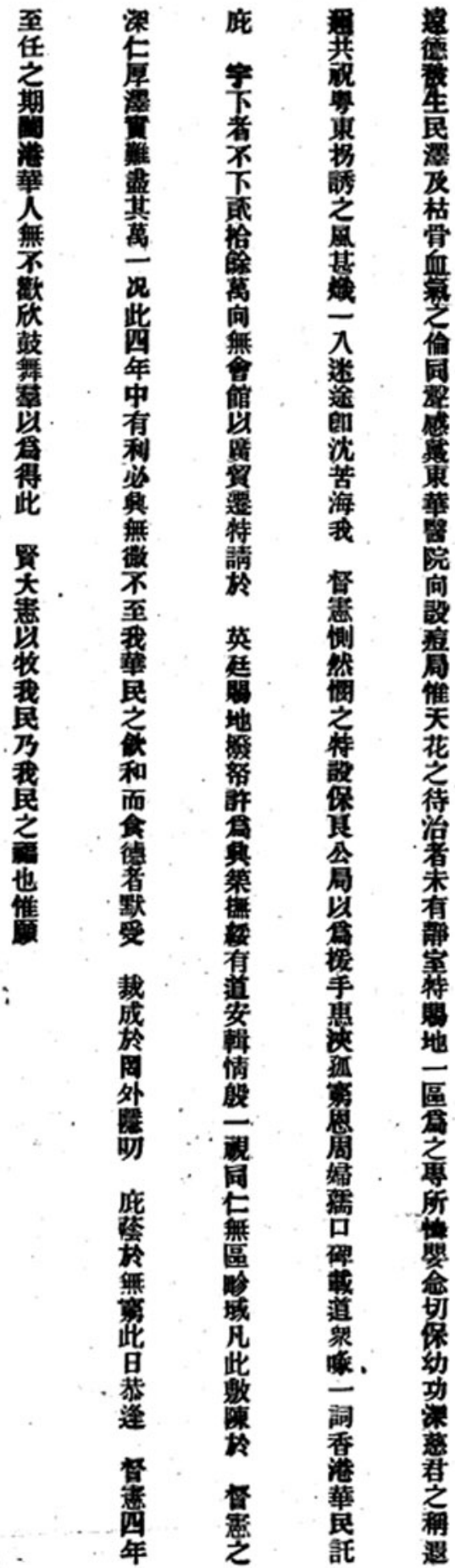


so that we may permanently enjoy his overshadowing and protecting influence, and rejoice beyond conception.

This is our congratulation.

In the Rnglish Year, 1881, the 22nd April.

In the 7 th Year of Kwong-sui, of the Ta. ts ing Dynasty, the 3nd Moon, the 24th day.

A congratulatory address by the Chinese people, gentry and merchants of the whole of Hongkong.

(Signed)

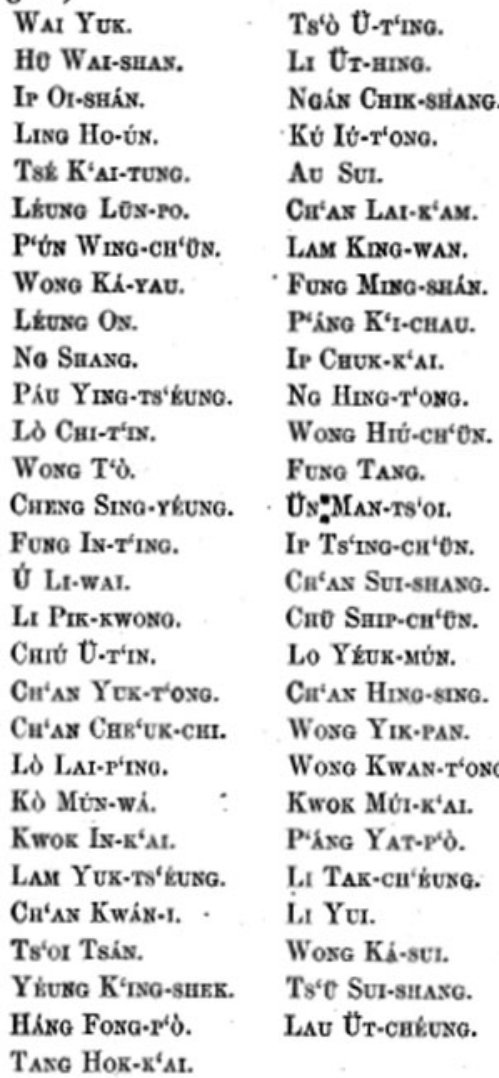

Translated by

E. J. Ertret.

23rd April, 1881

Sir Johs Pope Hrssissy thanked the deputation for their congratulations and good wishes, but as to the great prosperity of the Colony, he felt it was due far more to the merchapts, bankers and shopkeepers he saw in the deputation, than to any labours of his own. No doubt, within the last four years the value of property had

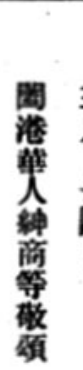

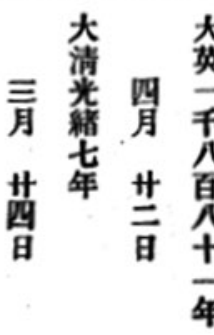

S4t

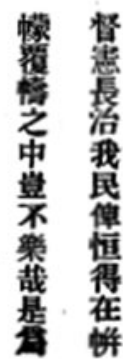

章王

鳘

許底臣

莱霹山

线可湎

证㹂東

整数坡

泟然川

步家粏

整安

㱑 泩

等庭的

1量些田

王 嫴

暗星照

㯊行庭

胡展虽

本堅兆

极用田

陳玉堂

略灼之

虚祻屏

高䩗華

船比滛

林鯮洋

倲明意

整 繁

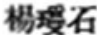

彭芳组

理鹤㴽

\section{名}

曹雨京

李月留

部植生

影耀堂

區迷

俥秱琴

林景雲

馮明理

起岐洲

菜竹溪

哭愛堂

畟晩川

馮

袁敏才

菜睛川

㽤瑞生

朱涉川

羅箕門

畹慶星

黄界窗

黄物堂

部梅溪

彭逸围

李徒昌

李 瑢

王家緒

推瞒生

劉乙章 
increased, the population had been augmented, two thousand new houses had been built, and whilst the inkabitants of the City of Victoria became more numerous, both by births and by immigration from the Kwang-tung province, crime bad diminished. But this was owing to the industry of the people, to their loyal and onderly disposition, and perbaps to some extent also to the practical advice be himself had received from time to time from those competent to give it as to the best mode of governing a Chinese community.

Her Majesty's Government had recognized this also in dealing with one of the subjects the depu. tation had mentioned, - that of kidnapping. Much had been done of late years to detect and punish this crime; and in 1879, Chief Justice Sir Jous SwaLE made a public ntterance on the subject which deservedly attracted great attention, His Honour very frankly remarking that be was sorry he had not noticed the matter before. But before the Chief Justice had noticed the evil in question, the gentleman who had introduced the deputation, and other gentlemen present had drawn the attention of the Government to it.

His Excellency then read the following extract from a despatch of the Earl of Kromearsx on the subject, dated Downing Street, 20th May, 1880:-

"With regard to kidnapping, the provisions of "the local law (Ordinance 4 of 1865 and 2 of "1875) ought to be sufficiently stringent, but "it appears that, the practice being on the "increase, certain Chinese gentlemen in Novem.

"ber 1878 asked permission to form themselves "into an Association for its prevention, and that a "Committee appointed by you to enquire into " the subject suggested that the petitioners should "form themselves into a Company for the purpose "under the 'Companies Ordinance, 1865'. I re. "quest that you will at once thank these Chinese "gentlemen for their offers of assistance in re. "pressing this form of crime, and that you will "allow them to form themselves into an Asso"ciation of whatever kind they desire. But in "order to obtain official recognition, its rules and "organization should be made known to and "approved by the Colonial Government. You "will, of course, give them such assistance as you

"may find practicable, and especially you will "instruct the Police to co-operate with them in

" bringing to justice all offenders whom they may "succeed in tracing. If the Association as It "first organized should be found insufficient, it

"will be time then to consider what other steps "should be taken."

The wisdom of Lord KIMBrRLEY's decision was to be seen in the fact that a considerable number of the kidnappers punished for the last twelve months had been detected and brought to justice by this Association of Chinese gentlemen. He might also remind them that in passing bis Ordinance No. 2 of 1875 , Governor Sir Astrus KrNNEDY had mentioned that he had introdaced it at the solicitation of the leading members of the Chinese community.

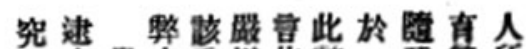

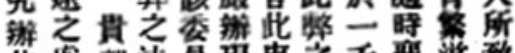

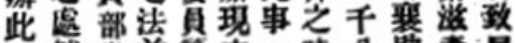

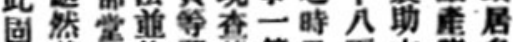

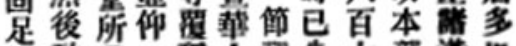
德的兄穆人趞先七部港也

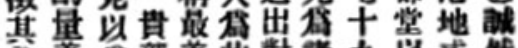

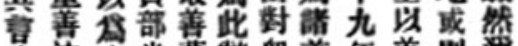

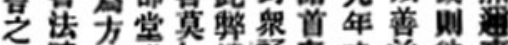
智等便准如端諍事時治萑来

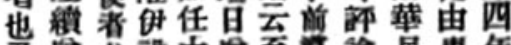

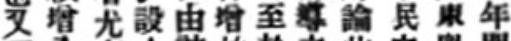

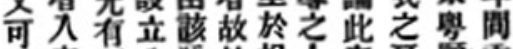

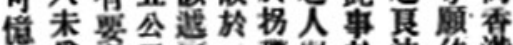

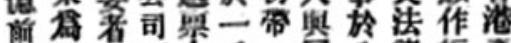

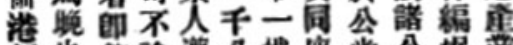

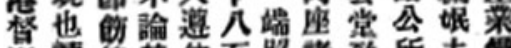

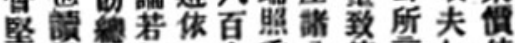

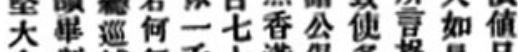

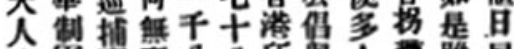

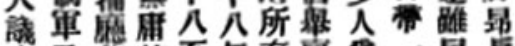

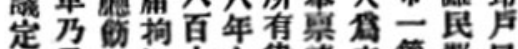
二云命泥交十律請之節数口 千整总但十二例感向旦人

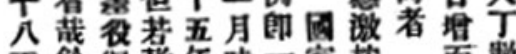

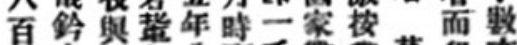

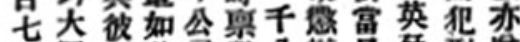

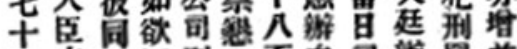
五之心國则百灰旬辩萑

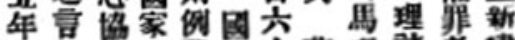
第留力認殿家士燕理該惹建 三通凡之亩思五制应事则愿

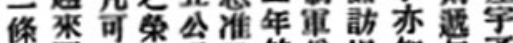
則西跟之间設第复埋知年不 例成踪则等立面将然之娍下

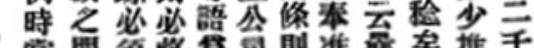

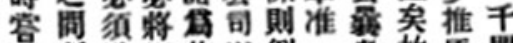
言所㫑邦此以例者故原间

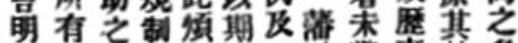

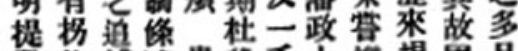

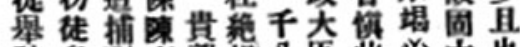
绫多制禀部荡八臣此心她

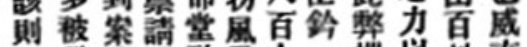

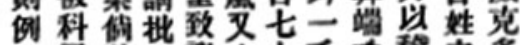

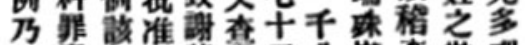

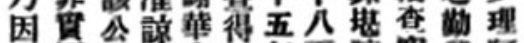
蒦因白人年百究究阿

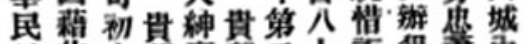

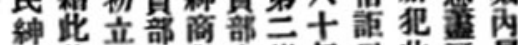
商花制堂倡堂佟年司些否居

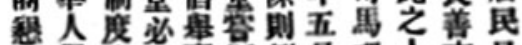

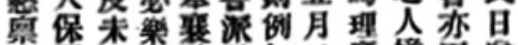

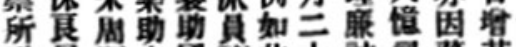

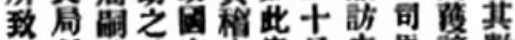
所後使家龺采旦未馬踖數 明莧彼禁此情登算理練或

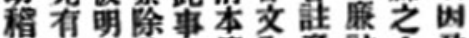
查希语此而應要訪人张 
His Excellency said that they were equally deserving of the thanks of the Government in another matter to which their address referred,the establishment of a small-pox hospital. It was true he had given them a little land, or, more properly speaking, he had given them permission to exeavate from the side of the hill near the Tung-wa Hospital, and to build on the site so formed a small-pox hospital, but they had formed this site and were erecting the building by means of their owa voluntary subscriptions. Furthermore, they maintained at their own cost a most efficient staff of native vaccinators, who travelled through the Island and along the adjoining coast, and to whose incessant labours His Excellency attributed the remarkable freedom of this Colony from the ravages of small-pox, in spite of the fact that we were exposed every year to the visits of many vessels more or less infected.

Such useful labours, as well as those to which the Earl of Krstisrarer referred, were not the only administrative functions which Her Majes. ty's Chinese subjects had shown themselves capable of discharging. In ' fact, in everything relating to the well-being of the Colony, he was glad, at all times, to receive their counsel and co-operation.

The deputation then withdrew.

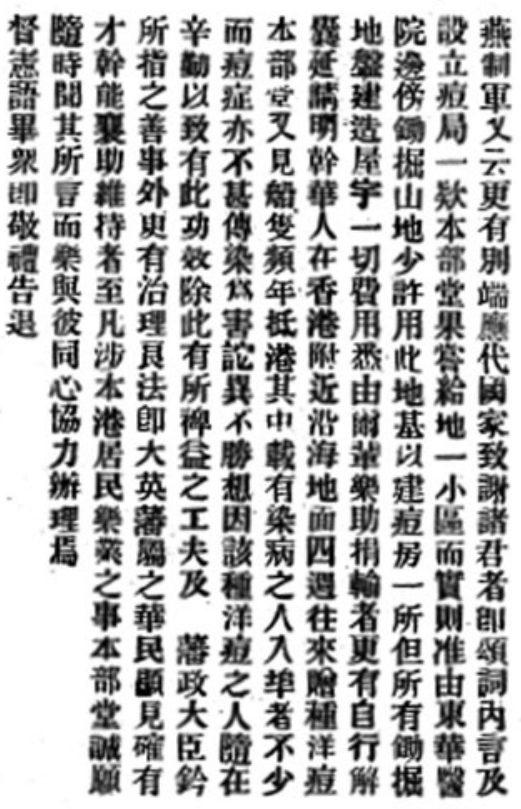

